\title{
Observation of Audouin's Gull Ichthyaetus audouinii in Suriname on South American mainland
}

\author{
Bert Kasius $^{1}$, Cees Witkamp ${ }^{2,4} \&$ Johan Ingels ${ }^{3}$ \\ Groene Draecksingel 59, 3451WB Vleuten, Netherlands. \\ Veldzichtlaan 54, 3461 GW Linschoten, Netherlands. \\ 3 In memoriam. \\ ${ }^{4}$ Corresponding author: Cees.Witkamp@vogelbescherming.nl
}

Received on 10 September 2018. Accepted on 05 March 2019.

\begin{abstract}
After a first-year Audouin's Gull Ichthyaetus audouinii was spotted in Trinidad on 10 December 2016, a second-year individual was now seen and photographed on 22 March 2018 in the mouth of the Suriname River near Paramaribo in Suriname. This record is the first of this species for that country and for mainland South America.
\end{abstract}

KEY-WORDS: Laridae, Mediterranean avifauna, Neotropical avifauna, rare vagrant.

Audouin's Gull Ichthyaetus audouinii (Payraudeau, 1826) is a large, maritime gull restricted to the Mediterranean Sea and the western coast of Saharan Africa and the Iberian Peninsula. Main breeding areas are the Ebro Delta in northeastern Spain and the Chafarinas Islands off north-eastern Morocco. Main wintering grounds are situated on the Atlantic coasts of north-western and western Africa, down to the south of Gambia and Senegal (Burger et al. 2018).

In the afternoon of 10 December 2016, Nigel Lallsingh, a birdwatcher in Trinidad, discovered a striking immature gull amongst a flock of roosting gulls, mainly Laughing Gulls Leucophaeus atricilla (Linnaeus, 1758), at the high tide roost in Brickfield $\left(10^{\circ} 20^{\prime} \mathrm{N} ; 61^{\circ} 16^{\prime} \mathrm{W}\right)$ on the west coast of Trinidad (Lallsing 2018). The gull was absent the following days until it was briefly seen on 14 January 2017. From 30 March to 03 April 2017, it was present at the same roost and seen and photographed by several local birdwatchers. This gull was a large and robust one with a sloping forehead and a long, rather droop-tipped bill. It was appreciably larger than the accompanying Laughing Gulls. It was in transitional plumage, moulting from firstwinter to first-summer plumage with faint grey-brown flecking on ear coverts and rear crown. Underparts were dirty white with extensive brownish mottling, and the upperparts were pale grey with large brownish blotching. When seen in March-April, and later on photographs taken in August, face and underparts were already whiter with just subdued pale grey mottling on upper breast and blotching on upperparts restricted to the nape. Mantle and wing coverts were paler grey with a few small brown blotches. Secondaries had white fringes and the inner primaries were much paler in contrast with dark outer ones (Kenefick 2017). These observations were submitted to the South American Classification Committee as proposal 772 (Kenefick 2018) and accepted as the first record of an Audouin's Gull for Trinidad and Tobago, and the first ever sighting of this species for "the Americas".

On 22 March 2018, when bird watching in the mouth of the Suriname River, B.K. accompanied by C.W. spotted a striking large and robust gull amongst a flock of smaller, roosting Laughing Gulls. It was sitting on a wooden construction in front of the police station near the fishing port of Nieuw-Amsterdam, c. $10 \mathrm{~km}$ downstream of Paramaribo $\left(c .05^{\circ} 53^{\prime} \mathrm{N} ; 55^{\circ} 06^{\prime} \mathrm{W}\right)$ at the confluence of the Suriname and Commewijne Rivers. Gulls are attracted to this place, where they feed on the waste of returning fishing boats.

Although he did not know about the record on Trinidad, B.K.'s first idea was that it was an Audouin's Gull. They took a digiscope photograph of the gull which they sent to their colleagues of the Vogelbescherming Nederland (BirdLife Netherlands) for further identification. Their colleagues in the Netherlands confirmed the identification as an Audouin's Gull in almost adult plumage. The gull was seen and photographed by several birdwatchers until at least 15 April (A.L. Spaans, pers. comm.). From these photographs, it is obvious that it is an Audouin's Gull moulting from second-winter into second-summer plumage. It had the typical dark primaries of a secondyear individual (Fig. 1) and a reddish bill with a black ring and a small yellow tip at the end (Fig. 2). See also 


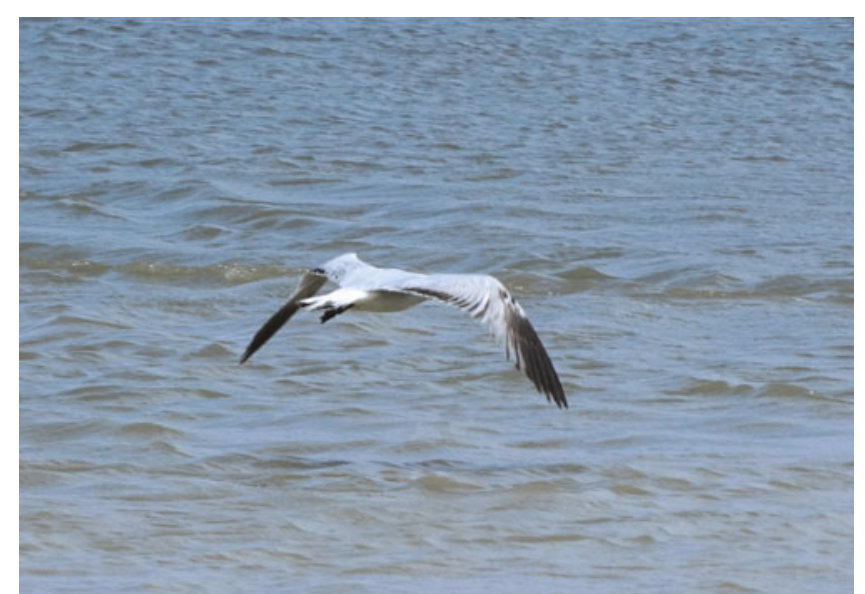

Figure 1. The Audouin's Gull Ichthyaetus audouinii in Suriname, photographed in flight showing the typical dark wing pattern of a second-year individual. Photo author: Bert Kasius.

plate 12 and 13 in Malling-Olsen \& Larsson (2003).

This observation is the first record for Suriname (Spaans et al. 2016) and for mainland South America. There is a possibility that the Audouin's Gull seen in Suriname, was the same as the one seen in Trinidad. The slow moulting after it was seen in first-winter plumage in December 2016 into second-summer plumage in March 2018 is consistent with this possibility. And the distance between the two localities where it was recorded is only $835 \mathrm{~km}$.

\section{ACKNOWLEDGEMENTS}

We thank Sean Dilrosum, Gini Dilrosum-Treurniet, Hans Dankbaar and Hans Majong for allowing us to use their observations and photographs. Discussions with and suggestions made by Jan Hein Ribot and especially Arie Spaans have been much appreciated. With his usual generosity, Des Jackson corrected the language and improved the lay-out of this short communication.

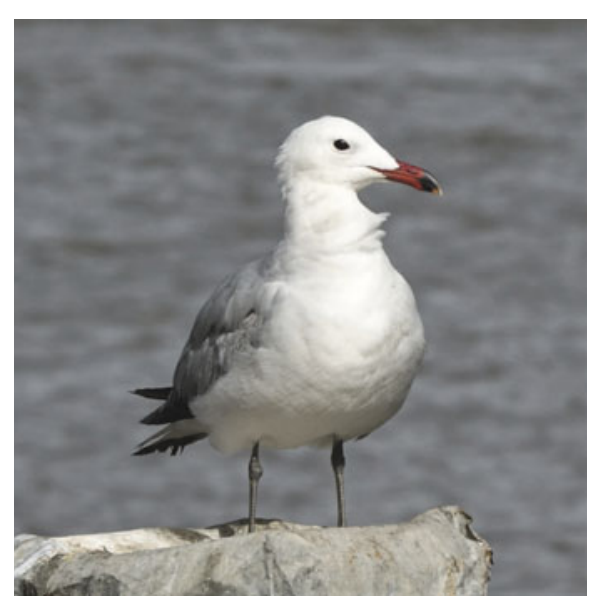

Figure 2. The second-year Audouin's Gull Ichthyaetus audouinii in Suriname. Note the adult colour pattern of the bill, dark eyes and grey legs. Photo author: Bert Kasius.

\section{REFERENCES}

Burger J., Gochfeld M., Garcia E.F.J. \& Sharpe C.J. 2018. Audouin's Gull (Larus audouinii). In: del Hoyo J., Elliott A., Sargatal J., Christie D.A. \& de Juana E. (eds.). Handbook of the birds of the world alive. Barcelona: Lynx Editions. https://www.hbw.com/ node/53971 (Access on 21 August 2018).

Kenefick M. 2017. Fourteenth report of the Trinidad and Tobago Birds Status and Distribution Committee: records submitted during 2016. Living World, Journal of the Trinidad and Tobago Field Naturalists' Club 1: 64-69.

Kenefick M. 2018. Proposal 772 to South American Classification Committee. Louisiana: Louisiana Museum of Natural Science. http://www.museum.lsu.edu/ Remsen/SACCprop772.htm (Access on 09 April 2018).

Lallsing N. 2018. A vagrant from the Old World: a mysterious gull in Trinidad. Neotropical Birding 22: 54-57.

Malling-Olsen K. \& Larsson H. 2003. Gulls of Europe, Asia and North America. London: Christopher Helm.

Spaans A.L., Ottema O.H. \& Ribot J.H.J.M. 2016. Field guide to the birds of Suriname. Leiden: Koninklijke Brill.

Associate Editor: Marcos P. Dantas. 